How to cite this article:

Abdulkarim, U. F., Mohammed, L., Mohammed, A. N., \& Abubakar, S. (2019). The effect of firm specific characteristics on financial leverage of quoted diversified companies in Nigeria. Malaysian Management Journal, Vol. 23(December), 27-46.

\title{
THE EFFECT OF FIRM SPECIFIC CHARACTERISTICS ON FINANCIAL LEVERAGE OF QUOTED DIVERSIFIED COMPANIES IN NIGERIA
}

\author{
UMAR FAROUK ABDULKARIM* \\ Department of Accounting and Finance, \\ Faculty of Management and Social Sciences \\ Federal University Gusau, Zamfara State, Nigeria \\ LAWAL MOHAMMED \\ AISHA NUHU MOHAMMED \\ SALISU ABUBAKAR \\ Department of Accounting, ABU Business School \\ Ahmadu Bello University, Zaria, Nigeria \\ *Corresponding author: elfarouk105@gmail.com
}

\begin{abstract}
Financial leverage decision by firm continues to attract interest from managers, analysts, researchers, scholars as well as policymakers because of its implications for the firm and its stakeholders. This paper investigates how the complexity of business, firms' dependence on external finance and growth opportunity affects the financial leverage decision among quoted diversified companies in Nigeria. The study took a census of six diversified firms quoted on the Nigerian capital market over the period of 10 years (2008-2017). Descriptive statistics and correlation matrix were employed with panel data analysis using Ordinary Least Square (OLS) robust model to analyse the data. The results from the study revealed that the complexity of business and growth opportunity is positive and significantly influencing the financial leverage of quoted diversified companies in Nigeria, while dependence on the external finance revealed a significantly negative effect on the financial leverage. It is recommended that the management of quoted
\end{abstract}


diversified companies in Nigeria should target an optimal capital structure in line of businesses that their streams of revenue are not positively correlated. This can be achieved by taking advantage of growth opportunities in the industries where they can further diversify their businesses and enhance profit generation.

Keywords: Complexity of business, Dependence on external finance, Growth opportunity, Diversified firms and financial leverage.

\section{Introduction}

Financing decision among firms has continued to constitute concern amongst managers, analysts, researchers, scholars as well as policymakers, especially with regards to the debts from financial institutions (Ukaegbu, 2015). Previous empirical studies conducted have shown that the diversified firms mostly employ low leverage in their choice of capital mix (Lewellen, 1997). This is due to the fact that they can rely on their internal capital market to alter their investment policies and subsequently raise cash through sales or transfer of cash from their subsidiaries (Jensen \& Meckling, 1976). More so, extant literature has shown that diversified firms carryout their transactions with their subsidiaries by means of tunnelling or propping, which entails the movement of financial resources from parent company to subsidiaries and vice versa, thus making external source of finance less attractive to them.

Quoted diversified firms in Nigeria constitute a significant percentage of the total market capitalization. Significant events within the diversified firms sector have the potential to affect the wider market making it worthwhile for researchers to focus and investigate them from time to time. Maksimovic and Phillips (2013) sees diversified companies as firms that operate in more than one industry where they have not demonstrated expertise, they are often multi-industry and most of the times, large and multinational cutting across number of economic sub-sectors such as consumer goods, oil and gas, banking and so forth. Therefore, it is important to understand how this particular characteristic that is unique to diversified firms affects the financing patterns and decision of quoted diversified companies in Nigeria.

Diversified firms are usually very large entities with either cross country operations (geographical diversification) or multi-product lines (product diversification) given their usual nature and scale of operations. Although theoretically it is believed that large companies are more likely to have 
huge debts in their funding structure due to their larger capacity for debt, Jensen and Meckling (1976) contended that diversified companies like conglomerates are more likely to keep a low level of debt due to their ability to reallocate capital across subsidiaries. The counterintuitive nature of the financing decision among diversified firms means that the findings within the general body of literature concerning the factors that drive leverage decisions in firms may not easily be generalized to them. Nonetheless, the impact of their leverage decision on their performance, on the markets and by extension on the economies of the countries within which they operate cannot be left untended.

Large body of the extant studies on the relationship between firm characteristics and debt financing emanates from more developed countries with significant difference in economic structure with Nigeria. Furthermore, the findings from these studies are quite mixed in view of the firms' attributes that affect the financing pattern of companies in different countries and sectors of the economy. For example, most of the studies concentrated on countries like United State (US), Canada, Italy, Japan, Korea, Thailand, and so forth (Tang \& Jang, 2007; Gill, Biger, Pai \& Bhut Ani, 2009; Gill \& Mathur, 2011; Rocca, Rocca, Gerace \& Smark (2009); Choi, 2014; \& Waranpee, 2011). The developing countries have had their own share of research as evidenced from the empirical literature on the factors that drive leverage decisions in firms (Hijazi \& Tariq, 2006; Mishran, 2011; Akinlo, 2011; Shehu, 2011; Regasa, 2013; Kiran, 2013; Srivastava, 2014).

Findings from these studies are mixed and as such do not provide a conclusive evidence on the factors that determine the leverage decision in diversified firms. The lack of consistency in findings may be due to differences in institutional settings, laws, rules and regulation guiding business activities in different countries (Rajan \& Zingales, 1995). Furthermore, the endogenous nature of leverage, which makes it sensitive to different measures of firm characteristics, differences in sample size, variable measurement may be additional factors that have contributed to the mixed findings (Lee, Yu \& Zhang, 2007).

In the Nigerian context, most studies concentrated on investigating firms' attributes like firm size, age, tangibility, profitability, liquidity, and growth opportunities among others with a large proportion of these empirical literatures such as those of Salawu and Agboola's (2008), Mutalib (2010), Akinlo's (2011), Shehu's (2011) and Suleiman's (2012) paying more attention to other domain to the exclusion of diversified companies. This research is focused on diversified companies and analysed a variable (complexity of business) that to the best of our knowledge has not been previously explored 
within the Nigerian context. Even within the body of literature from the developed economies, only a few studies established a direct link between the complexity of business and financial leverage. For instance, Gill and Mathur (2011) found the variable to be significant and positively influence Canadian manufacturing sector's financial decision. This leaves a research gap within diversified firms in Nigeria, which this present study intends to fill, with a view to providing a detailed understanding of their financing pattern.

This paper is aimed at assessing the impact of firm specific characteristics on financial leverage of quoted diversified companies in Nigerian. In line with the stated objectives of the study, the following hypotheses were stated in the null form:

$\mathrm{H}_{01}$ : Complexity of business has no significant effect on financial leverage of quoted diversified companies in Nigeria.

$\mathrm{H}_{02}$ : Dependence on external finance has no significant impact on financial leverage of quoted diversified companies in Nigeria.

$\mathrm{H}_{03}$ : Growth opportunity has no significant impact on financial leverage of quoted diversified companies in Nigeria.

The result of this research will help financial managers of diversified firms in Nigeria in understanding how the complexity of their business affects their borrowing decisions. It will also be of paramount importance to investors in understanding the growth opportunities awaiting their investment which will help in making optimal decisions as regards investing more capital or divesting from such sector. The remainder of this paper is organised and presented as follows: the review of prior literature which centres on firm characteristics vis-à-vis financial leverage and theoretical framework underpinning the research; the research methodology; analysis and discussion of result; conclusion and recommendation.

\section{Literature Review}

\section{The Concept of Financial Leverage}

Leverage is a concept that has been evolving from time immemorial. Theoretically, the concept has attracted attention most notably in the works of Modigliani and Miller (1958). The term leverage is seen as the amount of external finance a company utilised in financing its assets (Kuhlemeyer, 2004). Leverage is widely considered to be of two kinds: financial leverage which external finance used in financing purchase of asset and is related to fixed debt cost while operational leverage resulting from use of external 
finance for funding operational activities (Nissim \& Penman, 2003). According to Rehman (2013), financial leverage is the degree to which a firm used borrowed fund in executing its operation. This definition clearly pointed out that as borrowed money increases, the financial leverage (gearing ratio) also increases with its corresponding increase in finance charges and the risk of bankruptcy.

Pandey (2010) defined the concept of leverage as a source of capital with a finance cost attached to it, for example, preference capital with owner's equity in a capital structure of a firm. This definition shows that the debt providers have limited participation as regards partaking in the share of profit of a corporate entity, thus, they ensure the protection of the companies' earnings from which the payment of their fixed charges will come from. In all the aforementioned definitions of the concept of financial leverage, one thing is common, that is the use of debt to finance business operation or a project. The definition of Pandey (2010) is considered more encompassing which is adopted for this research. Firm specific characteristics are those factors that are endogenous to a firm and are capable of influencing their financing decision. Most of these factors are within the control of the management, because they are firm attributes or characteristics which are financial in nature (Suleiman, 2012). This may include but not limited to the complexity of business, dependence on the external finance and growth opportunity within the purview of this research work.

\section{Complexity of Business and Financial Leverage}

Business complexity which is often seen from the perspective of business diversification, increases firms' debt capacity while at the same time reduces their probability of bankruptcy (Lewellen, 1971). Hossain (2008) described complexity of business among Indian banks as the actual number of subsidiaries or divisions each bank has. This paper adopts the definition of Hossain (2008) in looking at the complexity of business as the number of subsidiaries a firm has. The complexity of business is among several factors that have been found to influence the financial leverage of various firms. For example, Ajay and Madhumathi (2012) examined the effect of diversification tactics on the debt financing decisions companies in Indian manufacturing firms. A sample of 579 multinational companies and 2524 domestic companies was used for a period of seven years from 2004 to 2010. The leverage was used as dependent variable while international market diversification and product diversification measured using herfindhal index approach as the sum of each industry sale as proportion of group total sales. The result revealed that the complexity of business has no significant effect on the leverage financing. 
Bricker, Grant, Fogarty and Previts (1999) conducted a study on the association between multinational firm complexity and analyst following. The result reveals that firm complexity is negative and significantly associated with analyst following. However, the study did not clearly define the scope used in terms of time dimension, thus leading to covering an indefinite period, which may render the findings of the study misleading as time passes by. Rocca, Rocca, Gerace and Smark (2009) examined the financial strategy of Italian multi-business firms. Panel data was used with the Generalised Method of Moment for a period of 27 years. The leverage was used as dependent variable while the product diversification inform of business segment was used as independent variable. The research revealed that the companies that followed the unrelated diversification approach try to reach their optimum debt level strictly.

On the contrary, Gill and Mathur (2011) examined the effects of financial leverage of listed 166 Canadian service companies during the period 2008 to 2010. Using leverage as the dependent variable while the complexity of business measured as number of subsidiaries of a firm was used as the explanatory variable. The research revealed that the number of subsidiaries is positive and significantly impacting on the financial leverage of Canadian Manufacturing Firms. While on the contrary, the period under study is too short for reaching logical conclusion. In another study, Hossain (2008) empirically investigated the degree of voluntary and mandatory disclosure of Indian banks with firm specific attributes. The research shows that the complexity of business is inversely insignificant. However, the time frame for the research is inadequate to make a meaningful generalisation on the population of the study. Thus, the outcome of the study should be accepted with great caution to avoid miss application judgment in terms of policy implication.

\section{Dependence on External Finance and Financial Leverage}

Dependence on the external finance has attracted formal attention most notably in the works of Rajan and Zingales (1998). In their study, they explained that new establishments are more likely to be new companies, and they rely more on outside investors compared to established companies. They observed dependence on the external finance as the degree to which a company is likely to rely on external financing in order to meet up with its operational needs for funds. It is measured as capital expenditures on property plant and equipment less cash flow from operations divided by capital expenditures. It shows how much gap does a firm have in operating cash flow and how much external financing does firm require at the end of 
the operating cycle to breach this gap. The definition of Rajan and Zingales (1998) is adopted by the research in measuring the variable.

Generally, there are scarces corporate empirical literature that explores the relationship between external finance dependence and debt financing. However, Von Furstenberg and Von Kalckreuth (2007) investigated the cyclically adjusted yearly measures of dependence on external finance received from the US industry statistics for the period 1977 to 1997. Annual values of external finance dependence were used instead of the firm level data. The findings of the study revealed that, variables that may be teamed as structural or technological have very low explanatory power and that dependence on the external finance figure received from the microeconomic data does not correspond from what is obtainable from aggregate figure; hence, Rajan and Zingales's (1998) assumption could not be validated.

In addition, Dodonov (2009) examined the effect of dependence on the external finance on firm-level volatility through the financial development in manufacturing and construction sectors in order to establish a link with the output volatility. The study was based on the general equilibrium model of the financial development that include risk-taking, risk-diversification, firmlevel, and aggregate volatility. The research showed a positive and significant influence of financial development on the firm-level volatility but stronger for companies in industries that are relatively more dependent on the external finance, ascribing it to technological characteristics of the industry thereby choosing higher risk-taking strategies.

\section{Growth Opportunity and Financial Leverage}

Penrose (1995) defined growth opportunity as an evolutionary process which involves the accumulation of knowledge unique to a firm. This unique knowledge about a firm may be factors affecting the firm internally or externally to its growth. The market to book value ratio use to proxy growth opportunity has an important influence on the debt financing of a company. According to Tang and Jang (2007), this is because a significant portion of the company's value comes from their intangible resources. Dakua (2018) empirically examined the effects of determinants on financial leverage in Indian steel industry for the period o 2010 to 2017. Using correlation matrix, regression analysis and stepwise regression in analysing the secondary data were extracted from the Centre for Monitoring Indian Economy Prowess database (CRISIL, 2018). The result of the study revealed the growth opportunity as an important variable in explaining the debt ratio. In responding to the need to investigate heterogeneity in the speed of adjustment to target leverage in UK firms, Fitzgerald and Ryan (2018) used a dynamic fractional 
panel estimator to investigate the effect of firm characteristics on speed of adjustment to target leverage. The study found that small high growth and low dividend paying firms adjust to target leverage faster than their large, low growth and high dividend paying counterparts.

Emeh and Okoli (2015) empirically investigated the characteristics that determine the capital structure in Nigerian oil and gas industry. The result revealed that growth opportunity is one of those factors in Nigerian oil and gas sectors. The findings of the study further revealed the funding pattern of oil and gas industry in Nigerian economy following a pecking order theory. In the same vein, Akingunola and Oyetayo (2014) conducted a pilot survey with a view to testing the existence and the strength of the financing pattern of Small and Medium Enterprises in Nigeria. The research revealed that the growth opportunity is positive and insignificantly associated to debt financing. Revising the determinant of capital structure of US lodging and software firms, Tang and Jang (2007) revealed that the growth opportunity and the joint effect of property plant and equipment with growth opportunity are significant with the financial leverage in both lodging and software firms. Finally, Waranpee (2011), explored the determinant of capital structure of Thailand quoted firms covering five years period revealed growth opportunity, was insignificant but directly related with financial leverage.

\section{Theoretical Framework}

This study is underpinned by the agency theory, pecking order theory and tradeoff theory. The agency theory propounded by Jensen and Meckling (1976) explains the conflict of interests between the shareholders called principals and managers called the agents or between shareholders and bondholders (Koopman, 2011). Leverage financing under this theory is seen as a tool of mitigating conflict between shareholders and managers (Ajay \& Madhumathi, 2012). However, under the special use of debt, the theory predicted that firms with conglomerate structure are more likely to eschew external debts. Therefore, our perspective of the relationship between complexity of business and leverage is based on the postulation of agency theory which predicts diversified firms like conglomerates are more likely to shun from external financing while depending more on funds from its internal capital market structure.

Modigliani and Miller's (1963) Tradeoff theory posited that firms increase their external financial obligation to a point where the additional tax benefits of marginal debt are equalised by the upsurge in the possibility of financial distress. Myers (1984) emphasised that firms who conform to the trade-off theory agreed on a target leverage ratio and steadily move toward achieving 
it due to the fact that finance costs are tax deductible, as such, utilising additional leverage increases the tax advantages. Therefore, faced with the growth opportunity, firms are likely to continue to seek external financing with a view of enjoying the tax advantage of debt until they reach their optimal capital structure. Nonetheless, where companies raise unnecessary external debt (to fund suboptimal projects) it may fail to meet its repayment schedule which may lead to additional bankruptcy costs. Consequently, the theory suggests that tax-shield benefit of debt should be adjusted for financial distress cost which correlates to debt levels (Brounen \& Eichholtz, 2001). However, in the case of diversified firms, this posited that the relationship between growth opportunity and debts may not hold all the time due to their inter-divisional lending which reduces the overall risk of bankruptcy of the conglomerate regardless of tax-advantage.

On the other hand, the pecking order theory developed by Myers and Majluf (1984) and further extended by Myers (1984) was rooted in the notion of Information asymmetry which implies that managers of corporate organisations have more information about their companies' projections, risks and profits compared to the external investors (Ajao \& Ema, 2013). Asymmetry of information gives managers the power to possess confidential knowledge on the companies' future prospects which outside investors are not aware of (Pandey, 2001). Everything being equal, when faced with high growth opportunities, managers will issue debt instead of equity with a view of transferring business risk of their investment decisions to bondholders at a fixed charge while keeping a majority of the profit from such investments to shareholders. This is due to the fact that equity is known to dilute control and ownership. The theory argues that managers will most likely issue equity when they are not sure about the growth opportunity.

Finally, the pecking order theory suggests that firms are more likely to increase financing their positive Net Present Value (NPV) projects using the cheapest sources of funds available to them. This implies that firms assume the non-existence of optimum capital structure, by following a priority of utilising the internal source, followed by secured debt to unsecured debt and then lastly to issuance of shares as the last resort. This hierarchical order, in which funds are assessed by a firm, clearly indicates that, the internal source of funds (retained earnings) are considered easier ways of generating fund followed by debt, which rank second and need to be serviced with fixed charge in form of interest payment. However, when firms are internally constrained, albeit and are highly dependent on external finance, they can hardly draw on retained earnings. Based on the pecking order theory, under this condition they are more likely to raise bonds instead of equity. However, among diversified firms the availability of internal capital market and the 
opportunity to leverage on it for funding instead of external debt can distort this behaviour. Therefore, based on the theories mentioned above, this study seeks to test the relationship complexity (agency), growth opportunity (pecking order) and dependence on the external finance (pecking order).

\section{Methodology}

\section{Data: Population and Sample}

This paper investigates the effect of firm specific characteristics on financial leverage of quoted diversified companies in Nigeria. In doing this, a correlational research design was adopted for the research because it is more appropriate in establishing the relationship and the extent to which firm specific characteristics affect financial leverage of quoted diversified firms in Nigeria. The population is limited to six diversified firms quoted on the Nigerian Stock Exchange for a period of 10 years (as at $31^{\text {st }}$ December, 2017). A census sampling approach was adopted which included six conglomerates companies.

\section{Variable Measurement}

Primarily, the research used three explanatory variables and one explained variable, which included leverage proxied by long term liability, and the firm characteristics proxied by the complexity of business, dependence on external finance and growth opportunity. The justification for choosing this proxy in measuring financial leverage is that the long-term debt is usually the preferred option in financing firm growth potentials in future among diversified companies and would also help in seeing the extent of their dependence on external finance.

Table 1

Measurement of Variables

\begin{tabular}{llll}
\hline Variables & Nature of variable & Measurement & Sources \\
\hline $\begin{array}{l}\text { Long term debt } \\
\text { (LTLB) }\end{array}$ & Dependent variable & $\begin{array}{l}\text { Measured as long } \\
\text { term liability divided } \\
\text { by total asset }\end{array}$ & $\begin{array}{l}\text { Tang and Jang (2007); } \\
\text { Mutalib(2010); Shehu } \\
\text { (2011). }\end{array}$
\end{tabular}

(continued) 


\begin{tabular}{|c|c|c|c|}
\hline Variables & Nature of variable & Measurement & Sources \\
\hline $\begin{array}{l}\text { Complexity of } \\
\text { business (CX) }\end{array}$ & $\begin{array}{l}\text { Independent } \\
\text { variable }\end{array}$ & $\begin{array}{l}\text { Measured as } \\
\text { Actual number of } \\
\text { subsidiaries }\end{array}$ & $\begin{array}{l}\text { Hossain (2008); Gill } \\
\text { and Mathur (2011). }\end{array}$ \\
\hline $\begin{array}{l}\text { Dependence } \\
\text { on external } \\
\text { finance } \\
\text { (DOF) }\end{array}$ & $\begin{array}{l}\text { Independent } \\
\text { variable }\end{array}$ & $\begin{array}{l}\text { Measured as capital } \\
\text { expenditure on } \\
\text { property, plant and } \\
\text { equipment less cash } \\
\text { flow from operation } \\
\text { divided by capital } \\
\text { expenditure }\end{array}$ & $\begin{array}{l}\text { Rajan and Zingales } \\
\text { (1995); } \\
\text { Von furstenberg and } \\
\text { Von Kalckreuth (2007). }\end{array}$ \\
\hline $\begin{array}{l}\text { Growth } \\
\text { opportunity } \\
(\mathrm{GW})\end{array}$ & $\begin{array}{l}\text { Independent } \\
\text { variable }\end{array}$ & $\begin{array}{l}\text { Measured as market } \\
\text { price of equity } \\
\text { divided by book } \\
\text { value. }\end{array}$ & $\begin{array}{l}\text { Myers (1984); Tang and } \\
\text { Jang (2007). }\end{array}$ \\
\hline
\end{tabular}

\section{Model Specification}

The model of the research is as follows:

$$
\mathrm{Ltlb}_{\mathrm{it}}=\beta_{0}+\beta_{1} \mathrm{CX}_{\mathrm{it}}+\beta_{2} \mathrm{DOF}_{\mathrm{it}}+\beta_{3} \mathrm{GW}_{\mathrm{it}}+\mu_{\mathrm{it}}
$$

where:

$$
\begin{aligned}
& \text { LTLB }=\text { Long Term Liability } \\
& C X=\text { Complexity of Business } \\
& D O F=\text { Dependence on External Finance } \\
& G W=\text { Growth Opportunity } \\
& \mu=\text { error term } \\
& \beta_{0}=\text { Intercept } \\
& \beta_{1}-\beta_{3} \text { parameters to be the estimate of the variables } \\
& \text { it }=\text { firm } i, \text { time } t \text { indicating a panel data } u \text { sed in the research }
\end{aligned}
$$

\section{Findings and Discussion}

This section presents the results of the descriptive statistics, followed by the correlation matrix and regression result of the research. Table 2 reveals that long term leverage shows a minimum and maximum value of 0.000 and 0.520 . This implies that there are diversified firms with no debt obligation in Nigeria in some years during the period of this research. However, the 
most leveraged diversified firms based on long term leverage only stood at 52 percent. The average long term leverage stood at approximately 0.13 percent. Looking at the long term leverage, it implies that diversified firms in Nigeria supports the theoretical proposition of Jensen and Meckling (1976) and the empirical works of Lewellen (1997) that diversified firms tend to eschew debt. Furthermore, the skewness and kurtosis show that the debt may be somewhat skewed and leptokurtic. The skewness of 1.30 and kurtosis 3.74 imply that, at levels, there are some outliers in the data, meaning that a few of the diversified firms have greater debt than the industrial average.

Table 2

Summary of Descriptive Statistics

\begin{tabular}{lccccccc}
\hline Variable & Observation & Mean & $\begin{array}{c}\text { Standard } \\
\text { deviation }\end{array}$ & Minimum & Maximum & Skewness & Kurtosis \\
\hline LTLIB & 60 & 0.128 & 0.142 & 0.00 & 0.520 & 1.30 & 3.74 \\
CPX & 60 & 6.250 & 3.138 & 2.00 & 14.00 & 0.81 & 2.55 \\
DOF & 60 & 1.106 & 2.770 & 0.01 & 14.087 & 3.97 & 17.79 \\
GW & 60 & 1.198 & 1.218 & 0.00 & 5.032 & 1.54 & 5.00 \\
\hline
\end{tabular}

The table further shows that complexity of business has an average mean value of six with a minimum value of two and a maximum value of 14 subsidiaries. This indicates that while some diversified firms have only a few subsidiaries, others have as much as 14 subsidiaries while the average number of subsidiaries among the conglomerates quoted on the NSE is about six subsidiaries. Dependence on external finance reveals an average value of 1.106. With its values ranging from a minimum of 0.01 to a maximum of 14.087 signifying that on the average diversified firms in Nigeria may require external financing beyond the cash flow that they generate for investment in property plant and equipment. On the other hand, growth opportunity which shows the growth potential of diversified firms in Nigeria has a mean value of 1.198. This value ranges from a minimum of 0.000 to a maximum of 5.032 which implies that diversified firms in Nigeria have good growth prospects.

\section{Correlation Matrix}

Table 3 presents the correlations matrix showing the relationship between the explained and the explanatory variable independent and among the explanatory variables. Table 3 reveals the association between the complexity of business and growth opportunity is weak and positively correlates with the financial leverage of quoted diversified firms in Nigeria; whilst the dependence on external finance is inversely related with the 
financial leverage of quoted diversified companies in Nigeria. Generally, the data shows a weak correlation among variables indicating the likelihood of absence of harmful multicollinearity in the data. The correlation coefficients may only be considered too harmful when it is approaching or above 0.80 (Gujarati, 2004).

Table 3

Correlation Matrix

\begin{tabular}{lcccc}
\hline & LTLIB & CPX & DOF & GW \\
\hline LTLIB & 1.0000 & & & \\
CPX & 0.0924 & 1.0000 & & \\
DOF & -0.2012 & -0.2553 & 1.0000 & \\
GW & 0.1110 & 0.0105 & 0.1867 & 1.0000 \\
\hline
\end{tabular}

Table 4

Multiple Estimation Result

\begin{tabular}{lclclll}
\hline Variables & Coefficient & S.E & $t$-statistics & $p$-values & Tolerance & VIF \\
\hline Constant & 0.009 & $(0.039)$ & 0.23 & 0.822 & & \\
CPX & 0.025 & $(0.009)$ & 2.57 & $0.013^{* *}$ & 0.997 & 1.00 \\
DOF & -0.007 & $(0.002)$ & -2.60 & $0.012^{* *}$ & 0.998 & 1.00 \\
GW & 0.066 & $(0.030)$ & 2.16 & $0.035^{* *}$ & 0.998 & 1.00 \\
$\mathrm{R}^{2}$ & 0.24 & & & & & \\
Adjusted R ${ }^{2}$ & 0.20 & & & & & \\
F-Statistics & 5.14 & & & & & \\
Probability. & $0.0033^{*}$ & & & & & \\
(F. sig)) & & & & & \\
\hline Note: * Corration is significant at 0.01 lisels $(2$ tailed);* Correlation is significant
\end{tabular}

Note: * Correlation is significant at 0.01 levels (2 tailed); ** Correlation is significant at 0.05 levels ( 2 tailed); $* * *$ Correlation is significant at 0.10 levels ( 2 tailed)

The regression result in Table 4 shows that the complexity of business (CXP) with a beta coefficient of 0.025 ( $p$-value 0.013 ) is significant and positively impacting the financial leverage of quoted diversified firms in Nigeria at 5 percent significance level. This means that for every one percent increase in the number of subsidiaries of diversified firms, financial leverage will rise by 
2.5 percent. The implication of this finding is, an increase in the number of subsidiaries increases the amount of financial leverage of quoted diversified companies in Nigeria. Thus the result produces a basis for rejecting the null hypothesis which states that complexity of business has no significant effect on financial leverage of quoted diversified companies in Nigeria. This result is in line with the findings of Gill and Mathur's (2011) but contrary to those of Grant et al.'s (1999), Rocca et al.'s (2009) and Ajay and Madhumathi's (2012). It is also clear from the findings of the study that the more a firm is expanding in to new line of business, the more the need for debt financing in the form of financial leverage in order to finance such expansion and the less available free cash flow for managers to exhibit opportunistic behaviour. This helps in reducing the conflict of interest among various stakeholders in the business which is not in line with the Agency theory as forwarded by Jensen and Meckling (1976) but supports the general understanding that larger firms tend to have more debt.

Furthermore, the dependence on external finance (DOF) with a beta coefficient of -0.007 ( $p$-value 0.012 ) is negative and the significant impact on financial leverage of quoted diversified firms in Nigeria at 5 percent significance level. This means that for every one naira increase in the need for external finance among diversified firms, financial leverage decrease by 0.07 naira. The negative impact of dependence on the external finance on financial leverage may not be unconnected with the fact that diversified firms rely on their internal capital market to alter their investment policies and subsequently raise cash in any of their subsidiaries as opined by Jensen and Meckling (1976). This result may render external finance less desirable among diversified firms. In line with the foregoing, the study rejects the second null hypothesis which states that dependence on the external finance has no significant impact on the financial leverage of quoted diversified companies in Nigeria. This is in line with the special use of debt hypothesis under the agency theory, where managers of corporate organisations shift the burden of debt, making it easier for them to generate capital internally and avoiding financial charges. The finding of the study is in line with Von furstenberg and Von Kalckreuth's (2007) work but contrary to that of Adam's (2002).

Finally, the model revealed that the growth opportunity (GW) with a beta coefficient of 0.066 ( $p$-values 0.035 ) is positive and significantly impacting on the financial leverage of quoted diversified companies in Nigeria at five percent significance level. This implies that for every one naira increase in growth opportunity of quoted diversified companies in Nigeria, the financial leverage will increase by approximately 0.07 percent. This implies that, the more a firm expands in any form, either by diversifying into new line of 
business, or establishing new subsidiaries, the more the need for external financing in the form of financial leverage or borrowing. In line with this result, the study rejects the third null hypothesis of the study which states that the growth opportunity has no significant impact on the financial leverage of quoted diversified companies in Nigeria. The positive significant relationship between growth opportunity and financial leverage of diversified companies in Nigeria implies that the firms with potential future growth opportunities have the incentive to collect more debt for further growth. This is in line with the proposition of trade-off theory as postulated by Modigliani and Miller (1963). The finding of the study is in line with that of Akinlo (2011) but contradict those of Kiran (2013) and Akingunola and Oyetayo (2014).

The combined and overall impact of the independent variables which include the complexity of business, dependence on external finance and growth opportunity on the financial leverage of quoted diversified firms in Nigeria, is shown on the model summary of the regression results. The F- statistics reveal that the overall level significance of the model is 5.14 showing the adequacy and fitness of the model of the study and is significant at $(0.0033)$ level. The coefficient of determination represented by $\mathrm{R}^{2}$ which stood at 20 percent indicates the changes in the explained variable caused by the explanatory variables as used in the research, while the remaining 80 percent of the changes are caused by the external factors of the model.

\section{Post Estimation Tests}

To test for the existence of heteroscedasticity, the present study used Breuch Pagan/Cook-Weisberg. The study revealed that $\mathrm{chi}^{2}$ of 8.18 with $p$-value of 0.0042 , implies the presence of heteroscedasticity and that the null hypothesis which states that the variation of the residual is constant (homoscedastic) is rejected. The study conducted multicollinearity test to see if there is correlation among the explanatory variables themselves, which may affect the result of the study. Hence, variance inflation factor (VIF) was carried out and the values for the explanatory variables are less than 10 as indicated with the VIF of 1.0 and the tolerance values for all the variables are greater 0.10 (threshold). This shows there is absence of multicollinearity. The Hausman specification test was carried out to choose between the random and fixed effects models.

The result of the Hausman test revealed that the value of $\mathrm{chi}^{2}$ is 1.17 and the prob $>$ chi 0.7597 . The insignificant value as reported by the probability of chi $^{2}$ indicates that the Hausman test is in favour of random effects model. Further to this, the Breusch and Pagan Lagrangian multiplier test for random effect was conducted to choose between the random effects result and OLS regression. The result deduced from the test showed $c^{2}{ }^{2}$ of 0.03 with the 
p-value of 0.8578 . This suggested the pool OLS model is appropriate for the study. The research went further and conducts the OLS robust to do away with the panel effect in the model and was adopted for the study.

\section{Conclusion and Recommendations}

This research investigated the effect of firm specific characteristics on financial leverage of quoted diversified companies in Nigeria. It was revealed that the complexity of business has significant and positive impacts on the financial leverage of quoted diversified companies in Nigeria. This implies that, the more diversified a company is, the more likely the company is to borrow, which is an indication that quoted diversified companies in Nigeria are fund growth. That is, as diversification increases, borrowing increases in order to fund such growth. In addition, dependence on the external finance has a negative but significant effect on the financial leverage of quoted diversified companies in Nigeria. This relatively implies that the firms within the quoted diversified companies in Nigeria may not rely on external finance, thus utilising internal capital markets as the alternative capitals due to the inverse relationship that exist among the variables of the study. The growth opportunity was positive and significantly influences the financial leverage of quoted diversified companies in Nigeria. This is because companies with the growth potentials have incentives (tax shield) to collect more debt for further expansion among quoted diversified companies in Nigeria.

The study recommends the shareholders within diversified companies in Nigeria to focus more attention on regulating expansion by management through borrowing, which is likely to dilute ownership and increase the risk of bankruptcy. The management of quoted diversified companies in Nigeria should encourage diversification in line of businesses that their streams of revenue are not positively correlated. This can be achieved by seeking growth opportunities in industries where they can further diversify their businesses to enhance profit generation, which will allow them to conveniently finance their subsidiaries and reduce bankruptcy risk through internal borrowing.

\section{References}

Adam, T. R. (2002). Do firms use derivatives to reduce their dependence on external capital markets? European Finance Review, 6(2), 163-187.

Ajao, O.S., \& Ema, I. U. (2013). International pragmatic review and assessment of capital structure determinants. Kuwait Chapter of Arabian Journal of Business and Management Review, 2(6), 82-95. 
Ajay, R., \& Madhumathi, R. (2012). Diversification strategy and its influence on the capital structure decisions of manufacturing firms in India. International Journal of Social Science and Humanity, 2(5), 421.

Akingunola, R., \& Oyetayo, O. (2014). Determinant of financial structure decision in small and medium enterprises: A pilot study of selected registered companies in Nigeria. Journal of Economics and Finance, $3(1), 2321-5925$.

Akinlo, O. (2011). Determinants of capital structure: Evidence from Nigerian panel data. African and Economics Business Review, 9(1), 16.

Ali, L. (2011). The determinants of leverage of the listed-textile companies in India. European Journal of Business and Management, 3(12), 54-59.

Banchuenvijit, W. (2011). Determinants of capital structure of listed companies in Thailand. School of Business, University of the Thai chamber of commerce. Retrieved from http://eprints.utcc.ac.th/id/ eprint/1694

Beck, T., \& Levine, R. (2000). External dependence and industry growth does financial structure matter? World Bank, Carlson School of Management, University of Minnesota.

Bricker, R. J., Grant, J., Fogarty, T. J., \& Previts. G. (1999). Determinant of analyst following. Journal of Corporate Communications, Social Science Research Network Electronic. Paper collection. Retrieved from http://papers. ssrn.com/paper.taf? abstract_id=220421

Choi, D. S. (2014). Determinants of the capital structure: Empirical study from the Korean market. International Journal of Science Commerce and Humanities, 2(7), 116-125.

Cole, R. A. (2013). What do we know about the capital structure of privately held US firms? Evidence from the survey of small business finance, financial management. De Paul University, Chicago.

Dakua, S. (2018). Effect of determinants on financial leverage in Indian steel industry: A study on capital structure. International Journal of Finance and Economics. Doi:10.1002/ijfe.1671.

Dodonov, B. (2009). Financial development, dependence on external finance and firm - Level volatility in manufacturing and construction sectors. University of Houston, Department of Economics, 204 McElhinney Hall, Houston.

Emeh, Y., \& Okoli, M. (2015). Determinants of capital structure in oil and gas sector in Nigeria. Merit Research Journal of Accounting, Auditing, Economics and Finance, 3(3), 32-45.

Fitzgerald, J., \& Ryan, J. (2018). The impact of firm characteristics on speed of adjustment to target leverage: A UK study, applied economics. DOI: $10.1080 / 00036846.2018 .1495822$ 
Gill, A., \& Mathur, N. (2011). Factors that influence financial leverage of Canadian firms. Journal of Applied Finance and Banking, 1(4), 107-123.

Gill, A., Biger, N., Pai, C., \& Bhutani, S. (2009). The determinants of capital structure in the service industry: Evidence from United States. The Open Business Journal, 2, 48-53.

Gujarati, D. N. (2004). Basic econometrics (4th ed.). USA: McGrew-Hill.

Hall, T. W. (2012). The collateral channel: Evidence on leverage and asset tangibility. Journal of Corporate Finance, 18(3), 570-583.

Hijazi, S. T., \& Tariq, Y. B. (2006). Determinants of capital structure: A case for Pakistani cement industry. Lahore Journal of Economics, 11(1), 63-80.

Hossain, M. (2008). The extent of disclosure in annual reports of banking companies: The case of India. European Journal of Scientific Research, 23(4), 659-680.

Jensen, M. C., \& Meckling, W. H. (1976). Theory of the firm: Managerial behavior, agency costs and ownership structure. Journal of Financial Economics, 3(4), 305-360.

Kiran, S. (2013). Determinants of capital structure: A comparative analysis of textile, chemical and fuel and energy sector of Pakistan. International Review of Management and Business Research, 2(1), 37-47.

Koopman, S. (2011). Firm characteristics and analyst following: A renewed perspective (Unpublished Master Thesis). University of Amsterdam.

Kroszner, R. S., Laeven, L., \& Klingebiel, D. (2005). Banking crises, financial dependence, and growth. University of Chicago: Graduate School of Business.

Kuhlemeyer, G. A. (2004). Fundamentals of financial managerial. New York: Pearson Education

Lee, Y. W., Yu, T., \& Zhang, T. (2007). Do corporations manipulate earnings to meet or beat analysts' forecasts? Evidence from pension plan assumption changes. Working paper, University of Rhode Island, Kingston.

Lewellen, W. G. (1971). A pure financial rationale for the conglomerate merger. The Journal of Finance, 26(2), 521-537.

Maksimovic, V., \& Phillips, G. M. (2013). Conglomerate firms, internal capital markets, and the theory of the firm. Annual Review of Financial Economics, 5(1), 225-244.

Marston, C. (1997). Firm characteristics and analyst following in the UK. British Accounting Review, 29, 335-347.

Mishran, C. S. (2011). Determinants of capital structure- A study of manufacturing sector PSUs in India. International Conference on Finance Management and Economics IPEDR. No.11, 247-252. 
Modigliani, F., \& Miller, M. H. (1958).The cost of capital, corporate finance and the theory of investment. The American Economic Review, 48(3), 261-275.

Mutallib, A. (2010). Determinant of capital structure in cement industry; A case of Nigerian listed cement firms. Nigerian Journal of Accounting, 6(1), 118-135.

Myers, S. C. (1984). The capital structure puzzle. Journal of Finance, 34(3), 575-592.

Myers, S.C., \& Majluf, N. (1984). Corporate financing and investment decisions when firms have information investors do not have. Journal of Financial Economics, 13, 187-221.

Nissim, D., \& Penman, S. H. (2003). Financial statement analysis of leverage and how it inform about profitability and price-to-book ratios. Review of Accounting Studies, 8, 531-560.

Olayinka, A. (2011). Determinants of capital structure: Evidence from Nigerian panel data. African Economic and Business Review, 9(1), 1-16.

Pandey, I. M. (2001). Capital structure and the firm characteristics: Evidence from an emerging market. Working paper. Indian Institute of Management Ahmed Abad.

Pandey, I. M. (2010). Financial Management. India: Vikas Publishing House.

Penrose, E. T. (1995). The theory of the growth of the firm. Oxford: University Press.

Rajan, R., \& Zingales, L. (1995). What do we know about capital structure? Some evidence from international data. Journal of Finance, 50, 421460.

Rajan, R., \& Zingales. L. (1998). Financial dependence and growth. The American Economic Review, 88(3), 559-586.

Raza, H., Aslam, S., \& Farooq, U. (2013). Financing pattern in developing nation empirical evidence from Pakistan. World Applied Sciences Journal, 22(9), 1279-1285.

Regasa, D. G. (2014). Determinants of leverage for unlisted firms: Evidence from Ethiopian private insurance companies. Journal of Poverty, Investment and Development, 4, 5-10

Rehman, S.S.F.U. (2013). Relationship between financial leverage and financial performance: empirical evidence of listed sugar companies of Pakistan. Global Journal of Management and Business Research Finance, 13(8), 33-40.

Rocca, L. M., Rocca, L.T., Gerace, D., \& Smark, C. (2009). Effect of diversification on capital structure. Journal of Accounting \& Finance, 49, 799-826. 
Salawu, R. O., \& Agboola, A. A. (2008). The Determinants of capital structure of large non-financial listed firms in Nigeria. The International Journal of Business and Finance Research, 2(2), 75-84.

Salawu, R. O. (2007). An empirical analysis of the capital structure of selected quoted companies in Nigeria. International Journal of Applied Economics and Finance, 1(1), 16-28.

Shehu, U. H. (2011). Determinants of capital structure in the Nigerian listed insurance firms. International Conference on Management Proceeding, 697-708.

Srivastava, N. (2014). Determinants of leverage of Indian companies: An empirical analysis: A study of cement industry Indian. Merit Research Journal of Art, Social Science and Humanities, 2(2), 21-24.

Suleiman, H. K. (2012). Firm specific, macroeconomic factors and capital structure of listed cement companies in Nigeria (Unpublished Doctoral Thesis). Ahmadu Bello University, Zaria.

Tang, C., \& Jang, S. (2007). Revisit to the determinants of capital structure: A comparison between lodging firms and software firms. International Journal of Hospitality Management, 26(1), 175-187.

Ukaegbu, I. O. (2015). The impact of profitability on capital structure and speed of adjustment: An empirical examination of selected firms in Nigerian stock exchange. Research in International Business and Finance. Retrieved from:http://dx.doi. org/10.1016/j.ribaf 2005. 03.004.

Ukaegbu. B., Oino. I., \& Dada. F.B. (2014).The impacts of ownership structure on capital structure and firm's performance in Nigeria. Research Journal of Finance and Accounting, 5(15), 82-89.

Von Furstenberg, G.M., \& Von Kalckreuth, U. (2007). Dependence on external finance: An inherent industry characteristic? Open Economies Review, 17(4-5), 541-559.

Wald, J. K. (1999). How firm characteristics affect capital structure: An international comparison. Journal of Financial research, 22(2), 161187.

Wanrapee, B.(2011). Capital structure determinants of Thai listed companies. In The Clute Institute International Academic Conferences, 1-8. 